\title{
WEIGHTED COMPOSITION OPERATORS FROM ZYGMUND TYPE SPACES INTO BLOCH TYPE SPACES
}

\author{
JUNTAO DU AND SONGXIAO LI*
}

Abstract. In this paper, we investigate the boundedness and compactness of weighted composition operators from Zygmund type spaces to Bloch type spaces.

Mathematics subject classification (2010): 47B33, 30H10.

Keywords and phrases: Weighted composition operator, Bloch type space, Zygmund type space, boundedness, compactness.

\section{REFERENCES}

[1] B. Choe, H. Koo And W. Smith, Composition operators on small spaces, Integral Equations Oper. Theory 56 (2006), 357-380.

[2] D. Clahane and S. STEVić, Norm equivalence and composition operators between Bloch/Lipschitz spaces of the unit ball, J. Ineq. Appl. 2006, Article ID 61018, (2006), 11 pages.

[3] F. ColonnA, New criteria for boundedness and compactness of weighted composition operators mapping into the Bloch space, Cent. Eur. J. Math. 11 (2013), 55-73.

[4] C. Cowen And B. Maccluer, Composition Operators on Spaces of Analytic Functions, CRC Press, Boca Raton, FL, 1995.

[5] P. Duren, Theory of $H^{p}$ Spaces, Academic press, New York, 1970.

[6] K. ESMAEILI AND M. LINDSTRÖM, Weighted composition operators between Zygmund type spaces and their essential norms, Integral Equations Oper. Theory 75 (2013), 473-490.

[7] Z. Hu AND S. WANG, Composition operators on Bloch-type spaces, Proc. Royal Soc. Edinburgh, 135 (2005), 1229-1239.

[8] Q. HU AND S. YE, Weighted composition operators on the Zygmund spaces, Abstr. Appl. Anal. 2012 (2012), Art. ID 462482.

[9] O. HYVÄRINEN AND M. LINDSTRÖM, Estimates of essential norm of weighted composition operators between Bloch-type spaces, J. Math. Anal. Appl. 393 (2012), 38-44.

[10] H. LI AND X. FU, A new characterization of generalized weighted composition operators from the Bloch space into the Zygmund space, J. Funct. Spaces Appl. Vol. 2013, Article ID 925901, 12 pages.

[11] S. Li AND S. STEvić, Composition followed by differentiation between Bloch type spaces, J. Comput. Anal. Appl. 9 (2) (2007), 195-206.

[12] S. Li AND S. STEvić, Volterra type operators on Zygmund space, J. Ineq. Appl. Vol. 2007, Article ID 32124, (2007), 10 pages.

[13] S. Li AND S. STEVIĆ, Generalized composition operators on Zygmund spaces and Bloch type spaces, J. Math. Anal. Appl. 338 (2008), 1282-1295.

[14] S. Li AND S. STEvić, Products of Volterra type operator and composition operator from $H^{\infty}$ and Bloch spaces to the Zygmund space, J. Math. Anal. Appl. 345 (2008), 40-52.

[15] S. Li And S. STEVIĆ, Weighted composition operators from Zygmund spaces into Bloch spaces, Appl. Math. Comput. 206 (2008), 825-831.

[16] S. Li AND S. STEVIĆ, Integral-type operators from Bloch-type spaces to Zygmund-type spaces, Appl. Math. Comput. 215 (2009), 464-473.

[17] S. Li AND S. STEVIĆ, On an integral-type operator from $\omega$-Bloch spaces to $\mu$-Zygmund spaces, Appl. Math. Comput. 215 (2010), 4385-4391. 
[18] S. Li AND S. STEVIĆ, Products of composition and differentiation operators from Zygmund spaces to Bloch spaces and Bers spaces, Appl. Math. Comput. 217 (2010), 3144-3154.

[19] B. MACCLUER AND R. ZHAO, Essential norm of weighted composition operators between Bloch-type spaces, Rocky. Mountain J. Math. 33 (2003), 1437-1458.

[20] K. Madigan And A. Matheson, Compact composition operators on the Bloch space, Trans. Amer. Math. Soc. 347 (1995), 2679-2687.

[21] J. MANHAS AND R. ZhaO, New estimates of essential norms of weighted composition operators between Bloch type spaces, J. Math. Anal. Appl. 389 (2012), 32-47.

[22] S. Ohno, K. Stroethoff And R. ZhaO, Weighted composition operators between Bloch-type spaces, Rocky Mountain J. Math. 33 (2003), 191-215.

[23] A. Shields AND D. Williams, Bounded projections, duality, and multipliers in spaces of analytic functions, Trans. Amer. Math. Soc. 162 (1971), 287-302.

[24] S. STEviĆ, Composition operators from the Hardy space to the Zygmund-type space on the upper half-plane, Abstr. Appl. Anal. Vol. 2009, Article ID 161528, (2009), 8 pages.

[25] S. STEVIĆ, On an integral operator from the Zygmund space to the Bloch-type space on the unit ball, Glasg. J. Math. 51 (2009), 275-287.

[26] S. STEvić, Composition operators from the Hardy space to Zygmund-type spaces on the upper halfplane and the unit disk, J. Comput. Anal. Appl. 12 (2010), 305-312.

[27] S. STEVIĆ, On an integral-type operator from Zygmund-type spaces to mixed-norm spaces on the unit ball, Abstr. Appl. Anal. Vol. 2010, Article ID 198608, (2010), 7 pages.

[28] S. STEVIĆ, Weighted differentiation composition operators from $H^{\infty}$ and Bloch spaces to $n-t h$ weigthed-type spaces on the unit disk, Appl. Math. Comput. 216 (2010), 3634-3641.

[29] S. STEvić AND A. Sharma, Composition operators from weighted Bergman-Privalov spaces to Zygmund type spaces on the unit disk, Ann. Polon. Math. 105 (2012), 77-86.

[30] S. STEvić, Z. Zhou AND R. Chen, Weighted composition operators between Bloch type spaces in the polydisc, Sb. Math. 201 (1-2) (2010), 289-319.

[31] H. Wulan, D. Zheng AND K. Zhu, Compact composition operators on BMOA and the Bloch space, Proc. Amer. Math. Soc. 137 (2009), 3861-3868.

[32] X. Zhang AND J. XIAO, Weighted composition between $\mu$-Bloch spaces on the unit ball, Sci. China 48 (2005), 1349-1368.

[33] R. ZHAO, Essential norms of composition operators between Bloch type spaces, Proc. Amer. Math. Soc. 138 (2010), 2537-2546.

[34] K. ZHU, Operator Theory in Function Spaces, Marcel Dekker, New York and Basel, 1990.

[35] X. ZHU, Generalized weighted composition operators on Bloch-type spaces, J. Ineq. Appl. 2015 (2015), 59-68. 